\section{PEMASANGAN BATAS \\ LINGKUNGAN , PAPAN \\ NAMA KEPALA DAN \\ IMAM LINGKUNGAN}

Oleh :

\author{
NURMITASARI
}

917390310010

Mita2416@gmail.com

\section{Bentuk kegiatan}

- Memasang batas lingkungan

- Memasang papan nama kepala lingkungan dan imam lingkungan

\section{Lokasi}

Kelurahan bontotangnga

kecamatan tamalatea

\section{Hari/Tanggal dan Waktu}

Senin , 02 november 2020 pukul 08:00

\section{Peserta yang dilibatkan}

Mahasiswa KKLP

\section{Alasan diadakan}

Untuk memberikan informasi kepada masyarakat dan pengguna jalan lainnya yang ingin mencari lokasi atau wilayah di lingkungan tertentu

\section{Tujuan dan Manfaat}

Kami mengadakan program kerja ini agar masyarakat lebih mudah mengetahui lokasi di lingkungan tersebut.

\section{Deskripsi kegiatan}

Proses pemasangan papan nama lingkungan ini di lakukan selama satu hari, pemasangan ini di lakukan agar masyarakat lebih mudah mengetahui batas wilayah serta lokasi di lingkungan tersebut. 